\title{
An analytical study of Hygiene Practices and its Impact of Health status of the household
}

\author{
Dr. S. S. Apate', Mr. Nishant Kamble ${ }^{2}$ \\ ${ }^{1}$ Faculty, ${ }^{2}$ Research Scholar \\ Chhatrapati Shahu Institute of Business Education and Research, Kolhapur, Maharashtra, India
}

\begin{abstract}
Organised By:
Management Department, Chhatrapati Shahu Institute of Business Education and Research, Kolhapur, Maharashtra

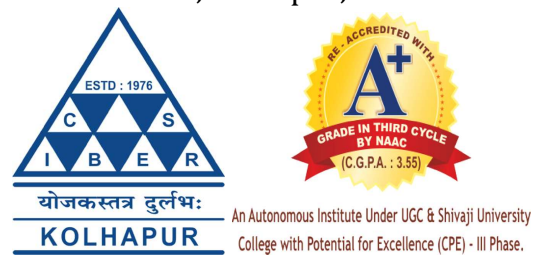

How to cite this paper: Dr. S. S. Apate | Mr. Nishant Kamble "An analytical study of Hygiene Practices and its Impact of Health status of the household" Published in International Journal of Trend in Scientific Research and Development (ijtsrd), ISSN: 2456-6470, Special Issue | Fostering Innovation, Integration and Inclusion Through Interdisciplinary

Practices in

Management, March

2019, pp.152-159,

URL:

https://www.ijtsrd. com/papers/ijtsrd2 3089.pdf

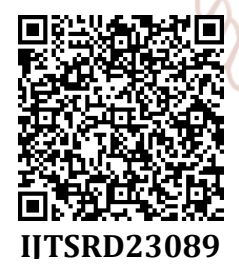

Prevailing High Infant Mortality Rate is also largely attributed to poor sanitation Programme (CRSP) was launched in 1986 primarily with the objective of improving the quality of life of the rural people and to provide privacy and dignity to women.

The concept of sanitation was earlier limited to disposal of human excreta by cess pools, open ditches, pit latrines, bucket system etc. today it connotes a comprehensive concept, which includes liquid and solid waste disposal, food hygiene, personal, domestic as well as environmental hygiene.

\section{LITERATURE REVIEW}

1. (Sah, Khadgi, \& Jha, 2017)Haveassessed the knowledge and practice regarding hygienic conditions among residents of Rangeli Municipality of Morang District. Hey have measured the association between sociodemographic characteristics and disease pattern with

\section{STACT} water, sanitation and health. Consumption of uns dring disposal of human excreta, improper environmental sanitation and lack of sonal and food hygiene have been major causes of many diseases in do this. Sanitation is one of the sanitary practices prevent contamination of water and soil and thereby prevent diseases. The concept of sanitation was, therefore, expanded to include personal , home sanitation, safe water, garbage disposal, excreta disposal and followed by the household in the PanhalaTaluka. For the study hygiene index result reveals that households are following the hygiene practices in terms of defection and hand washing habits, however the score is less in terms of water related hygiene practices and domestic waste management.

\section{KEYWORDS: Sanitation, Hygiene Index} water, sanitation and health. Consumption of unsafe drinking water, improper disposal of human excreta, improper environmental sanitation and lack of personal and food hygiene have been major causes of many diseases in developing countries and India is no exception to this.

hygienic practices of the study population. Their study reveals that majority of samples had good knowledge and practice regarding hygiene.Overall prevalence of hygienic practices of this study was $77.7 \%$. Higher economic condition and those did not suffer from diarrhea in previous one year was significantly associated with hygienic practices.

2. (Rayamajhi, et al., 2014)have done a research on A Study On Sanitary And Hygiene Practices In ChungwangVdc Of Dhankuta District, Eastern Nepal through their extensive research they found that Only $97.4 \%$ of the respondents washed hands with soap and water though in reality though $99.3 \%$ of them had soaps in their households. Similarly, $81.2 \%$ of the respondents had provision of toilet at their home but $79.2 \%$ used it regularly. This showed the importance of behavioral change and communication among the participants rather than health awareness alone. Basic hand washing 
International Journal of Trend in Scientific Research and Development (IJTSRD) @ www.ijtsrd.com eISSN: 2456-6470

was practiced by everyone during/after defecation and before meal but the importance of it after cleaning the bottom and nose of children and before preparing the meal was known to few of the participants.

3. (Tearfund, February 2007)Tear fund is an evangelical Christian relief and development agency working with local partners to bring help and hope to communities in over 70 countries around the world. They had done investigation in Madagascar about development of policies on sanitation and hygiene at national level and implementation of sanitation and hygiene programmes and found positive factors relating to sanitation and hygiene are sanitation and hygiene policy, stakeholder dialogue in Madagascar, led by the national WASH platform strong leadership shown by certain individuals also have some barriers like low budgetary priority, education ministry is a secondary player in sanitation and hygiene policy-making and issue of choice and sequencing of different types of development intervention.

4. (Tan, Cheng, Soon, Ghazali, \& Mahyudin, 2013)in their research article "A Qualitative Study On Personal Hygiene Knowledge And Practices Among Food" have done a study to determine personal hygiene knowledge among 25 food handlers at 12 selected primary schools in Klang Valley area, Selangor, Malaysia. A qualitative approach using in-depth interviews was employed and respondents were selected by a convenience sampling. The results showed that the respondents had basic knowledge on personal hygiene practices, mainly on hand washing $(30.7 \%)$ and glove use $(18.7 \%)$. The food handlers $(<11 \%)$ also demonstrated their knowledge on other good personal hygiene practices that were related to the use of hair restrain/cap/apron, keeping tidy hair/ clean nails / clean hand, no bare hand contact with food, not wearing ring/jewelry, no smoking, tidy/clean attire and typhoid injection. Most respondents (>70\%) practiced glove use, however more than $50 \%$ did not wash hands with every glove change, change gloves when change type of products and after preparing raw material. The study showed that the food handlers have basic knowledge one good personal hygiene practices. However, some discrepancies were revealed in the proper hand washing procedure. This study recommended good hand washing procedure to be reiterated among the food handlers. There is also an immediate need for continuous training among food handlers regarding good personal hygiene practices.

5. (Islam, July,2012)Focused on personal hygiene but also discuss about street-vended food. This study was attempted to find out knowledge, attitude and practices about personal hygiene among East West University students. Their study examined for other risk factors of poor personal hygiene practices. Results of the study were showed that those students are very alert about their personal hygiene. Their hand washing habit is very good. But students (98\%) take street-vended food which is very harmful for their health. Students who are coming from outside of Dhaka have some poor personal hygiene practices habit comparing who live permanently in Dhaka city with their family.
Most of the study are focusing on defection habits as a hygiene practices. Hygiene practice is a multidimensional concept it includes-

A. Drinking water practices,

B. Hand washing practices

C. Defection practices and

D. Domestic waste management practices.

Present study has assessed the impact of all these hygiene practices on household health status.

Objectives of the Study

$>$ To understand the hygiene practices followed by the people in Panhala Taluka.

$>$ To analyse the relationship between health status and hygiene practices followed by the people.

\section{Hypotheses}

Hypothesis No.1

$>\mathrm{H}_{0}$ : Hospital and medical expenditures of the family are independent to hygiene practices followed by the household.

Hypothesis No.2

$>\mathrm{H}_{0}$ : Hygiene practices followed by the respondents are independent to their income.

\section{Research Methodology}

Data Collection: In the view of the given objectives, the present research work is carried out with the help of both secondary data and primary data was collected.

A. Primary Source - To collect the Primary data Survey method was adopted. Through conducting extensive literature survey researcher prepared questionnaire. The components of the questionnaire are as follows:

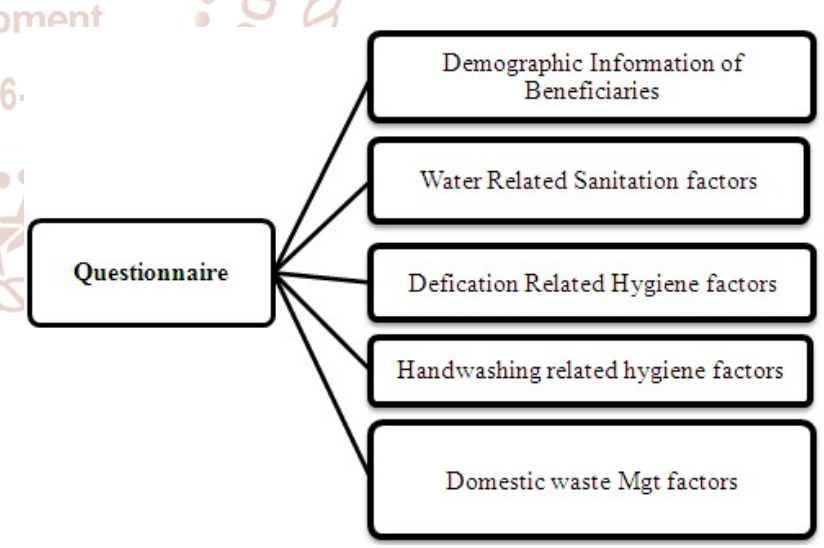

B. Secondary Source: in order to study the problem different secondary data sources were taped, such as:

$>$ Already published research papers.

$>$ Bulletin, Magazine, Reports of Central Government and State Government \& Journals

$>$ Shivaji University's Library and Library of other educational institute and Universities, etc.

1.6.2 Sample Design: To contact the study Stratified Multistage Random sampling method was used.

Procedure for collecting the samples was as follows:

1. Total geographical area of Panhala Taluka was divided as per Jilaha Parishad constituencies. There are four constituencies in the Taluka. 
International Journal of Trend in Scientific Research and Development (IJTSRD) @ www.ijtsrd.com eISSN: 2456-6470

2. Three villages from each Taluka were selected randomly.

3. From these villages, beneficiary households and Gram Panchayat members were contacted for collecting information.

4. Final respondent under the study was contacted using simple random sampling method.

Procedure for sampling the respondents:

A. Number of respondents to be contacted from each village was estimated using proportion to population sample size estimation method.

B. List of household from each village was procured. Each household was given one unique number in M.S. office excel.

C. By using random number generator programming for each village numbers were generated. To avoid no response error for each village five extra random numbers were generated.

D. Respective numbered household was contacted for collecting the data.

1.6.3 Sample Size: Total households of the villages selected for the study was calculated. It is the total population under the study.

Calculation of the Sample Size is as follows.

Population Size: 4644 is the total household in the selected villages

Confidence level: $95 \%$

Confidence interval: $\pm 5 \%$

Sample size estimating method: Percentage or Proportion sample size estimating method.

Formula:

\section{Where:}

$$
n=\frac{z^{2} \cdot p \cdot q \cdot N}{e^{2}(N-1)+z^{2} \cdot p \cdot q}
$$

Research

$\mathrm{n}=$ Size of Sample.

$\mathrm{N}=$ Size of Population (46444)

$\mathrm{z}=1.96$ (as per table of area under normal curve for the

given confidence level of $95 \%$ )

$\mathrm{p}=$ Sample proportion $(0.5)$

$\mathrm{q}=1-\mathrm{p}(1-0.5=0.5)$

$\mathrm{e}=$ Confidence interval $\pm 5 \%(0.05)$

By calculating the above equation sample size of the study was 379 households from the selected villages.(Kothari, 2006)

\section{Primary Data Source:}

The research instrument used for collecting primary data was a questionnaire, which are most widely used data collection methods in evaluation research. The structured questionnaire is used for the data collection. The questions from the questionnaire were close ended question. Researcher has collected primary data from the respondents in the scope of sample size. Questionnaires were circulated and get filled by the respondents from the research area. Researcher helps respondents to understand and filling of the questionnaire. It helped to gather information on opinions, views, relations, facts, and other information.

\subsection{The Analysis Has Done In Three Parts}

A hygiene practice is a multidimensional concept. This study has adopted a holistic perspective towards assessing the level of hygiene practices following in the study area. It studied the composite impact of hygiene practices followed and its impact on health condition in the given study area.

The researcher has prepared an index to assess the level of hygiene practices followed in the study area. The components of the index are as follows.

\section{Water Related Hygiene practices:}

Water is one of the important medium of spreading health diseases. Many a times drinking water provided in the rural area is contaminated. As there is no access for clean drinking water people have to drink unhealthy water. Besides, unhealthy drinking water supplied from its source, unhealthy water handling practices also cause contamination of drinking water. In rural area there is no daily supply of drinking water; household members have to walk long distance for fetch the water. Hence they fetch more amount of water in their free time and store it for more days. There are chances of water contamination is it is stored for more days. Using clean utensil for drinking water storage is important. Improper cleaning of drinking water storing utensils also leads to water contamination. Spread of water related diseases can be controlled by effective sterilizing the drinking water. Here is assessed what extent rural people do drinking water sterilization.

\section{Defecation Related Hygiene:}

Open defection is the most unhygienic practices followed in India. It is route cause of spreading the health diseases like Maleriya, dehydration and other viral diseases. There are various socio-economic factors influencing on peoples preferences to follow open defection practices. Indian Government has made huge effort to change peoples attitude and convince them to use toilet for defection. It is not only for defection but urinate also Indians goes in open space. It is checked what extent Indians use toilets for urinate and defection.

\section{Hand washing habits:}

Transmitting of viral diseases can be control effectively by following daily hand watching practices. Infection can be control through using soap for watching hands. It is checked what extent hand watching practices are followed in the rural area. It is checked whether respondents watch their hands daily after doing various tasks. Such as defection, returning from work etc.

\section{Domestic Waste Management:}

Proper disposal of domestic waste ensures the hygiene and clean environment. Disposal of waste ensures timely decomposition of the waste. It also helps to avoid dirty smell. Mosquitos' birth can be control by proper domestic waste management. The score is given to the respondents who follow the healthy domestic waste management practices.

To prepare the index in detail review of index preparation methods is done. The procedure of preparation of Human development index 2017 is studied. To prepare the Hygiene index, Women's empowerment in agriculture index prepared by International Food Policy Research Institute (IFPRI)is referred and same methodology is followed for construction of Hygiene index.

Below table depicts the questions in each domain used for the construction and evaluation of the Hygiene Index. 
International Journal of Trend in Scientific Research and Development (IJTSRD) @ www.ijtsrd.com eISSN: 2456-6470

Table No. Hygiene index with questions in each domain.

\begin{tabular}{|c|c|c|c|c|}
\hline Domain & Questions & Response & $\begin{array}{l}\text { Value assigned for } \\
\text { index }\end{array}$ & $\begin{array}{l}\text { Max Score } \\
\text { for the } \\
\text { domain } \\
\end{array}$ \\
\hline \multirow{20}{*}{ Water Related Hygiene } & \multirow{6}{*}{$\begin{array}{l}\text { For how many days you } \\
\text { store drinking water }\end{array}$} & 1 day (No Store) & 5 & \\
\hline & & 2 days & 4 & \\
\hline & & 3 days & 3 & \\
\hline & & 4 days & 2 & \\
\hline & & 5 days & 1 & \\
\hline & & 6 days & 0 & \\
\hline & \multirow{6}{*}{$\begin{array}{l}\text { Within how many days } \\
\text { you clean the utensils }\end{array}$} & 1 day & 5 & \\
\hline & & 2 days & 4 & \\
\hline & & 3 days & 3 & \\
\hline & & 4 days & 2 & \\
\hline & & 5 days & 1 & \\
\hline & & 6 days & 0 & \\
\hline & \multirow{3}{*}{$\begin{array}{l}\text { Whether you sterilized } \\
\text { your drinking water }\end{array}$} & Through out year & 2 & \\
\hline & & Only in Rainy season & 1 & \\
\hline & & Never & 0 & \\
\hline & \multirow{5}{*}{$\begin{array}{l}\text { Grade the quality of your } \\
\text { drinking water. }\end{array}$} & Very Good & 4 & \\
\hline & & Good & 3 & \\
\hline & & Neither Good Not Bad & 2 & \\
\hline & & (c) & 1 & \\
\hline & & Very Bad & 0 & \\
\hline \multirow{14}{*}{$\begin{array}{l}\text { Defecation Related Hygiene } \\
\text { Habits }\end{array}$} & Whether toilet is & \begin{tabular}{|c|} 
Yes \\
\end{tabular} & 5 & \\
\hline & $\begin{array}{l}\text { available at your home } \\
\text { q14 }\end{array}$ & NRD No ? & 2 & \\
\hline & \multirow{6}{*}{$\begin{array}{l}\text { where generally Male } \\
\text { members urinates } \\
\text { where generally Female } \\
\text { members urinate }\end{array}$} & Private Toilet & 8 & \\
\hline & & \begin{tabular}{|l|} 
In \\
Public Toilet \\
\end{tabular} & 8 & \\
\hline & & arch Open Space & $P$ & \\
\hline & & Loprivate Toilet $\circlearrowleft$ & 8 & \\
\hline & & \begin{tabular}{|c|} 
Public Toilet \\
\end{tabular} & 2 & \\
\hline & & 456-0pen Space & 0 & \\
\hline & \multirow{3}{*}{$\begin{array}{l}\text { where generally Male } \\
\text { members defecate }\end{array}$} & \begin{tabular}{|l} 
Private Toilet \\
\end{tabular} & 2 & \\
\hline & & Public Toilet & 1 & \\
\hline & & $=$ Open Space & 0 & \\
\hline & \multirow{3}{*}{$\begin{array}{l}\text { where generally Female } \\
\text { members defecate }\end{array}$} & Private Toilet & 2 & \\
\hline & & Public Toilet & 1 & \\
\hline & & Open Space & 0 & \\
\hline \multirow{20}{*}{$\begin{array}{l}\text { Hand Washing Habits } \\
\text { Whether your family } \\
\text { members wash their hands } \\
\text { after doing following task. }\end{array}$} & \multirow{4}{*}{ Returning from work. } & Always 1 & 3 & \\
\hline & & Many a times 2 & 2 & \\
\hline & & Some Time & 1 & \\
\hline & & Never & 0 & \\
\hline & \multirow{4}{*}{ After defecation } & Always & 3 & \\
\hline & & Many a times & 2 & \\
\hline & & Some Time & 1 & \\
\hline & & Never & 0 & \\
\hline & \multirow{3}{*}{$\begin{array}{l}\text { After cleaning small kids } \\
\text { defecation }\end{array}$} & Always & 3 & \\
\hline & & Many a times & 2 & \\
\hline & & Some Time & 1 & \\
\hline & \multirow{3}{*}{ Animal Husbandry } & Never & 0 & \\
\hline & & Always & 3 & \\
\hline & & Many a times & 2 & \\
\hline & \multirow{3}{*}{ Before Cooking Food } & Some Time & 1 & \\
\hline & & Never & 0 & \\
\hline & & Always & 3 & \\
\hline & \multirow{3}{*}{ Before having food } & Many a times & 2 & \\
\hline & & Some Time & 1 & \\
\hline & & Never & 0 & \\
\hline
\end{tabular}


International Journal of Trend in Scientific Research and Development (IJTSRD) @ www.ijtsrd.com eISSN: 2456-6470

Domestic Waste

Management

17 wou through your

domestic waste

\begin{tabular}{|c|c|c|}
\hline & & \\
\hline & Dispose it properly & 5 \\
\hline Whether there is dustbin & Yes & 2 \\
\hline near by your village & No & 0 \\
\hline Whether there is & Yes & 2 \\
\hline garbage collection van & No & 0 \\
\hline Whether ducthin is & Always & 2 \\
\hline cleaned regularly & Some time & 1 \\
\hline & Never & 0 \\
\hline & Every day & 3 \\
\hline How often garbage & Alternative day & 2 \\
\hline & Twice in a week & 1 \\
\hline & Never & 0 \\
\hline & Very Good & 3 \\
\hline How you grade the & Good & 2 \\
\hline cleanness of your area. & Bad & 1 \\
\hline & Very Bad & 0 \\
\hline
\end{tabular}

The answers to each question included in the Hygiene Index are converted into the score by multiplying values assigned for index. These values are added up within each domain and then divided by the number of items under each domain and score of each domain is ascertained.

Results:

Following table shows the descriptive statistics of Mean score Hygiene practices followed by the respondents in the PanhalaTaluka.

\begin{tabular}{|c|c|c|c|}
\hline Domain & N & Mean & Std. Deviation \\
\hline Water Related Hygiene & 379 & 58.5917 & 13.38160 \\
\hline Defecation Related Hygiene & 379 & 92.6324 & 16.87586 \\
\hline Hand Washing Habits & 379 & 88.4638 & 20.31575 \\
\hline Domestic Waste Management & 379 & 47.1364 & 16.32380 \\
\hline & 379 & & \\
Hygiene Index Result \\
Hen
\end{tabular}

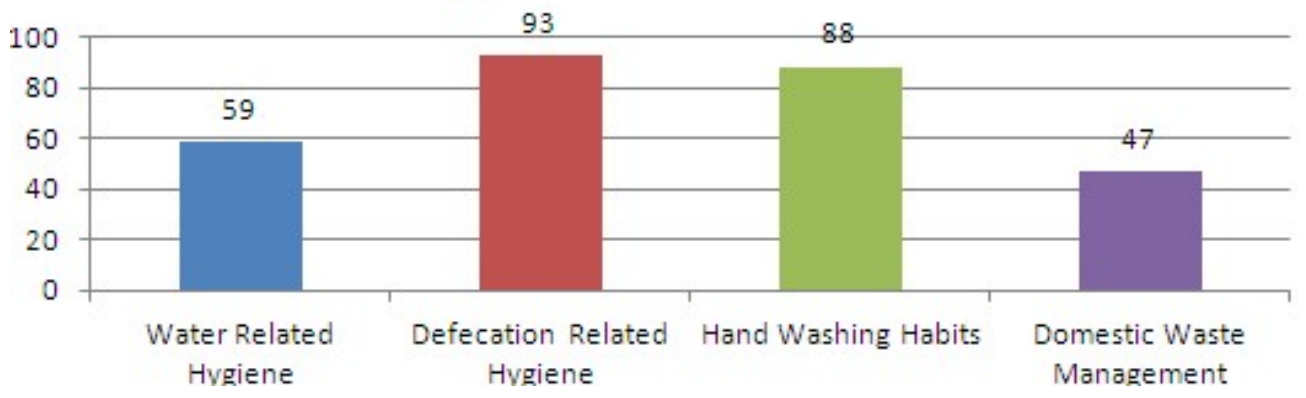

Interpretation:

Above graph reveals that Defecation related hygiene practices score is maximum at 93 percent. It is encouraging to state that people defecation habits have been changing. People have almost shifted from the open defection to use of toilet. The governments have done huge efforts to generate awareness among the population to use toilets. The findings reveal that the results are fruitful. People are using toilets not only for defecation but also for urinate. The study findings also supports the Maharashtra Government sanitation report which has stated that Kolhapur district has became open defection free district.

\section{Hypotheses Testing}

Here researcher has tested the stated hypothesis with appropriate statistical tools. The result of hypothesis is presented below.

Hypothesis No.1: Hygiene Practices and Family Health. One of the important objectives of this research is to assess the relationship between hygiene practices and family health status of the respondent. Hygiene practices of the respondents were measured by Hygiene Index prepared by the researcher. Health status of the family is assessed on the basis of the proportion of income they spend on the hospital and medical charges. Respondents were asked to state the proportion of the income of their family they send on the hospital and medical charges. The response is between 1 percent to 5 percent 6 percent to 10 percent, 11 percent to 
15 percent 16 percent to 20 percent, 20 percent to 25 percent and more than 25 percent.

The statement of the hypothesis is as follows.

$\mathrm{H}_{0}$ : Hospital and medical expenditures of the family are independent to hygiene practices followed by the household.

Here dependent variable is the proportion of the income family spends on hospital and medical charges. It is categorical variable and one out of given six response is possible. Predicator variable, family hygiene practices are measured using hygiene index score of the each family. It is continuous variable.

\section{Hypothesis test used:}

To Multinomial logistic regression (often just called 'multinomial regression') is used to predict a nominal dependent variable given one or more independent variables. It is sometimes considered an extension of binomial logistic regression to allow for a dependent variable with more than two categories. As with other types of regression, multinomial logistic regression can have nominal and/or continuous independent variables and can have interactions between independent variables to predict the dependent variable.

The test results are presented as follows:

Model Fitting Information: table is used to test the overall model fit. The Model Fitting Information table, as shown below:

\begin{tabular}{|c|c|c|c|c|}
\hline & del Fitting & rmatio & & \\
\hline \multirow{2}{*}{ Model } & $\begin{array}{l}\text { Model Fitting } \\
\text { Criteria }\end{array}$ & \multicolumn{3}{|c|}{$\begin{array}{l}\text { Likelihood Ratio } \\
\text { Tests }\end{array}$} \\
\hline & $\begin{array}{c}-2 \text { Log } \\
\text { Likelihood }\end{array}$ & $\begin{array}{l}\text { Chi- } \\
\text { Square }\end{array}$ & df & Sig. \\
\hline $\begin{array}{c}\text { Intercept } \\
\text { Only } \\
\text { Final }\end{array}$ & $\begin{array}{l}497.039 \\
390.976\end{array}$ & 106.063 & 12 & .000 \\
\hline
\end{tabular}

Here the "Final" row presents information on whether all the coefficients of the model are zero (i.e., whether any of the coefficients are statistically significant). It state whether the variables added statistically significantly improve the model compared to the intercept alone (i.e., with no variables added). The results from the "Sig." column that $p=.000$, which means that the full model statistically significantly predicts the dependent variable better than the interceptonly model alone.

In multinomial logistic regression you can also consider measures that are similar to $R^{2}$ in ordinary least-squares linear regression, which is the proportion of variance that can be explained by the model. In multinomial logistic regression, however, these are pseudo $R^{2}$ measures and there is more than one, although none are easily interpretable. Nonetheless, they are calculated and shown below in the

Pseudo R-Square table:
\begin{tabular}{|c|c|}
\hline Cox and Snell & .244 \\
\hline Nagelkerke & .300 \\
\hline McFadden & .166 \\
\hline
\end{tabular}

SPSS Statistics calculates the Cox and Snell, Nagelkerke and McFadden pseudo $R^{2}$ measures. Of much greater importance are the results presented in the Likelihood Ratio Tests table, as shown below:

\begin{tabular}{|c|c|c|c|c|}
\hline \multicolumn{5}{|c|}{ Likelihood Ratio Tests } \\
\hline \multirow[b]{2}{*}{ Effect } & \multirow{2}{*}{$\begin{array}{c}\begin{array}{c}\text { Model Fitting } \\
\text { Criteria }\end{array} \\
-2 \text { Log } \\
\text { Likelihood of } \\
\text { Reduced } \\
\text { Model }\end{array}$} & \multicolumn{3}{|c|}{$\begin{array}{c}\text { Likelihood Ratio } \\
\text { Tests }\end{array}$} \\
\hline & & $\begin{array}{c}\text { Chi- } \\
\text { Square }\end{array}$ & df & Sig. \\
\hline Intercept & 416.730 & 25.754 & 3 & .000 \\
\hline $\begin{array}{l}\text { Water } \\
\text { Related } \\
\text { Hygiene }\end{array}$ & 432.718 & 41.741 & 3 & .000 \\
\hline $\begin{array}{c}\text { Defecation } \\
\text { Related } \\
\text { Hygiene }\end{array}$ & 391.222 & .246 & 3 & .970 \\
\hline $\begin{array}{c}\text { Hand } \\
\text { Washing } \\
\text { Habits }\end{array}$ & 407.288 & 16.311 & 3 & .001 \\
\hline $\begin{array}{c}\text { Domestic } \\
\text { Waste } \\
\text { Managemen }\end{array}$ & 395.442 & 4.465 & 3 & .215 \\
\hline
\end{tabular}

This table shows which of your independent variables are statistically significant. It is seen that water related Hygiene factor is statistically significant $(\mathrm{P}$-value $=0.000)$ at 5 percent level of significant, Defecation related hygiene factors is not statistically significant $(\mathrm{P}-\mathrm{value}=0.970)$. Hand washing habits hygiene factors is statistically significant $(\mathrm{P}$-value $=0.000)$ is significant at 5 percent level of significant and domestic waste management related hygiene factors is not statistically significant $(\mathrm{P}$-value $=.215)$

\section{Hypothesis No.2. Hygiene Practices and Income.}

Further researcher has studied whether there is any relationship between hygiene practices followed by the respondents and their Income.

\section{Statement of Hypothesis:}

H0: Hygiene practices followed by the respondents are independent to their income.

Hypothesis test used: The one-way analysis of variance (ANOVA) is used to determine whether there are any statistically significant differences between the means of two or more independent (unrelated) groups (although you tend to only see it used when there are a minimum of three, rather than two groups).

Following table shows the income wise descriptive statistics of hygiene practices followed by the respondents. 
International Journal of Trend in Scientific Research and Development (IJTSRD) @ www.ijtsrd.com eISSN: 2456-6470

\begin{tabular}{|c|c|c|c|c|c|c|c|c|c|c|}
\hline \multicolumn{11}{|c|}{ Descriptive } \\
\hline & & \multirow[b]{2}{*}{$\mathbf{N}$} & \multirow[b]{2}{*}{ Mean } & \multirow{2}{*}{\multicolumn{2}{|c|}{$\begin{array}{l}\text { Std. } \\
\text { Deviation }\end{array}$}} & \multirow{2}{*}{$\begin{array}{l}\text { Std. } \\
\text { Error }\end{array}$} & \multicolumn{2}{|c|}{$\begin{array}{l}95 \% \text { Confidence } \\
\text { Interval for Mean }\end{array}$} & \multirow{2}{*}{ Minimum } & \multirow{2}{*}{ Maxin } \\
\hline & & & & & & & $\begin{array}{l}\text { Lower } \\
\text { Bound }\end{array}$ & $\begin{array}{l}\text { Upper } \\
\text { Bound }\end{array}$ & & \\
\hline \multirow{6}{*}{$\begin{array}{c}\text { Defecation } \\
\text { Related } \\
\text { Hygiene }\end{array}$} & Up to 1 Lakh & 265 & 93.85 & \multicolumn{2}{|c|}{15.75} & 0.97 & 91.94 & 95.75 & 38.46 & 10 \\
\hline & Up to 2 lakh & 43 & 90.88 & \multicolumn{2}{|c|}{15.95} & 2.43 & 85.97 & 95.78 & 38.46 & 10 \\
\hline & Up to 3 Lakh & 40 & 85.38 & \multicolumn{2}{|c|}{22.43} & 3.55 & 78.21 & 92.56 & 30.77 & 10 \\
\hline & Up to 4 Lakh & 10 & 86.92 & \multicolumn{2}{|c|}{27.63} & 8.74 & 67.16 & 106.69 & 30.77 & \\
\hline & More than 5 Lakh & 21 & 97.44 & \multicolumn{2}{|c|}{8.88} & 1.94 & 93.39 & 101.48 & 61.54 & \\
\hline & Total & 379 & 92.63 & \multicolumn{2}{|c|}{16.88} & 0.87 & 90.93 & 94.34 & 30.77 & 10 \\
\hline \multirow{6}{*}{$\begin{array}{l}\text { Hand } \\
\text { Washing } \\
\text { Habits }\end{array}$} & Up to $1 \mathrm{Lakh}$ & 265 & 92.91 & \multicolumn{2}{|c|}{18.77} & 1.15 & 90.64 & 95.18 & 0.00 & \\
\hline & Up to 2 lakh & 43 & 74.81 & \multicolumn{2}{|c|}{20.19} & 3.08 & 68.59 & 81.02 & 38.89 & 10 \\
\hline & Up to 3 Lakh & 40 & 70.42 & \multicolumn{2}{|c|}{18.20} & 2.88 & 64.59 & 76.24 & 38.89 & \\
\hline & Up to 4 Lakh & 10 & 77.22 & \multicolumn{2}{|c|}{17.06} & 5.40 & 65.02 & 89.43 & 50.00 & \\
\hline & More than 5 Lakh & 21 & $\begin{array}{c}100.0 \\
0\end{array}$ & \multicolumn{2}{|c|}{0.00} & 0.00 & 100.00 & 100.00 & 100.00 & \\
\hline & Total & 379 & 88.46 & \multicolumn{2}{|c|}{20.32} & 1.04 & 86.41 & 90.52 & 0.00 & 10 \\
\hline \multirow{6}{*}{$\begin{array}{c}\text { Domestic } \\
\text { Waste } \\
\text { Managem } \\
\text { ent }\end{array}$} & Up to $1 \mathrm{Lakh}$ & 265 & 43.20 & 10.3 & & 0.64 & 41.94 & 44.45 & 0.00 & 10 \\
\hline & Up to 2 lakh & 43 & 53.49 & 26. & & 4.05 & 45.32 & 61.66 & 0.00 & 10 \\
\hline & Up to $3 \mathrm{Lakh}$ & 40 & 63.68 & 21.8 & & 3.46 & 56.68 & 70.68 & 11.76 & 10 \\
\hline & Upto 4 Lakh & 10 & 70.59 & 10. & & 3.16 & 63.44 & 77.74 & 58.82 & 88. \\
\hline & More than 5 Lakh & 21 & 41.18 & 0.0 & 0 & 0.00 & 41.18 & 41.18 & 41.18 & 41. \\
\hline & Total & 379 & 47.14 & 16. & & 0.84 & 45.49 & 48.79 & 0.00 & 10 \\
\hline & Up to 1 Lakh & 265 & 54.55 & 9.7 & & 0.60 & 53.37 & 55.73 & 31.25 & 87 \\
\hline & Up to 2 lakh & 43 & 66.28 & 16.2 & 26 & 2.48 & 61.27 & 71.28 & 25.00 & 106 \\
\hline Water & Up to 3 Lakh & 40 & 76.09 & 13. & & 2.15 & 71.75 & 80.43 & 37.50 & 106 \\
\hline $\begin{array}{l}\text { Kelated } \\
\text { Hygiene }\end{array}$ & Up to 4 Lakh & 10 & 73.75 & 5.7 & 4 & 1.82 & 69.64 & 77.86 & 62.50 & 81. \\
\hline & More than 5 Lakh & 21 & 53.27 & 9.6 & $1 \cup 1$ & 2.10 & 48.90 & 57.65 & 43.75 & 68. \\
\hline & Total & 379 & 58.59 & $\operatorname{ter} 13$. & 38 na & \begin{tabular}{l|l}
$0.69 n$ & 1 \\
\end{tabular} & 57.24 & 59.94 & 25.00 & 106 \\
\hline & & 8 & 20 & & & & $\theta$ & 2 & & \\
\hline & & & & & $\mathrm{ANOV}$ & & & & & \\
\hline & & & & & Sum & of Squares & df & Mean Squar & $F$ & Sig. \\
\hline & & & Between G & roups & elo 3 & 434.689 & 4 & 858.672 & 3.081 & .016 \\
\hline Defe & cation Related Hygie & & Within Gr & oups & 10 & 4217.651 & 374 & 278.657 & & \\
\hline & & & Total & ISSN & 210 & 7652.340 & 378 & 2 & & \\
\hline & & & Between G & roups & & 355.486 & 4 & 7588.872 & 22.587 & .000 \\
\hline & and Washing Habits & & Within $\mathrm{Gr}$ & oups & 12 & 5656.273 & 374 & 335.979 & & \\
\hline & & & Total & $4>0$ & -15 & 5011.759 & 378 & & & \\
\hline & & & Between G & roups & & 037.377 & 4 & 5759.344 & 27.727 & .000 \\
\hline Dom & stic Waste Managem & ent & Within Gr & oups & 77 & 686.984 & 374 & 207.719 & & \\
\hline & & & Total & & 10 & 0724.361 & 378 & & & \\
\hline & & & Between $\mathrm{G}$ & roups & & 010.427 & 4 & 5502.607 & 45.055 & .000 \\
\hline & ater Related Hygien & & Within Gr & oups & & 676.949 & 374 & 122.131 & & \\
\hline & & & Total & & & 687.376 & 378 & & & \\
\hline
\end{tabular}

Above table reveals all score on all four hygiene index is significant at $5 \%$ level. Defecation Related Hygiene (P-value is .016), Hand Washing Habits (P-value is 0.00), Domestic Waste Management (P-value is 0.00) and Water Related Hygiene (P-value is 0.00 ). Hence the null hypothesis is rejected and it is concluded that hygiene practices followed by the respondents dependents on income on the household. From descriptive statistics it is revealed that as income improves the hygiene score of the respondents also improve.

\section{Conclusion}

Individual health and hygiene is largely dependent on adequate availability of drinking water and proper sanitation. Therefore, a direct relationship between water, sanitation and health. Consumption of unsafe drinking water, improper disposal of human excreta, improper environmental sanitation and lack of personal and food hygiene have been major causes of many diseases in developing countries and India is no exception to this. The Central Rural Sanitation Programme (CRSP) was launched the scheme Total Sanitation Campaign in 1968. The main aim of the scheme is improving the quality of life of the rural people and provides privacy and dignity to women. "Total Sanitation Campaign (TSC)" emphasizes more on Information, Education and Communication (IEC), Human Resource Development, Capacity Development activates to increase awareness among the rural people and generation of demand for sanitary facilities. The present study is an assessment of awareness and impact of Total sanitation practices in rural Panhala Taluka of Kolhapur district. For the study household from the Taluka were contacted and information was collected using simple random sampling 
International Journal of Trend in Scientific Research and Development (IJTSRD) @ www.ijtsrd.com eISSN: 2456-6470

method. On the basis of data collected household hygiene practices index is prepared. The index score reveals that the household are comparatively following good hygiene practices for defection and hand washing habits. Whereas there are score of water storage hygiene practices. It is discouraging to state here that the score of domestic waste relating practices are worst. It is because in most of the villages there are not provisions for dustbin and waste collection vans. To improve this situation researcher has suggested that people awareness, education and action is the solution. Expected objectives of sanitation programs can be achieved through people participation. Role of rural leaders are of paramount important, Universities, schools colleges shall get involved in awareness generation of sanitation program and practices. Rural youth organization and play significant role in this direction. Besides relying on mass media campaign personalized door to door contact and street plays demonstrations will helps to achieve desired objectives.

\section{Reference}

[1] Abdelrazig, A., Mustafa, K., \& Mohamed, M. (2017). Hygienic Practices among Food Handlers in Restaurants of Al-Nohod Locality Market-West Kordofan-Sudan-2017. International Journal of Public Health \& Safety .

[2] Akter, T., \& Ali, A. (2014). Factors influencing knowledge and practice of hygienein Water, Sanitation and Hygiene (WASH)programme areas of Bangladesh Rural AdvancementCommittee. The International Electronic Journal of Rural and Health Education practicies and policies , 1-10.

[3] Arulchelvan, S., \& Uma Maheswari. (December 2013,). Awareness and IEC Exposure on Sanitation/ Hygiene among the Rural People. Asian Journal of Research in Social Sciences and Humanities, Vol. 3, No.12,.

[4] Dwivedi, P., \& Sharma, A. (2007). A Study on Environmental Sanitation, Sanitary Habits and Personal Hygiene among the Baigas of Samnapur Block of Dindori District, Madhya Pradesh. J. Hum. Ecol , 7-10.

[5] Hossain, M. M. (July,2012). A STUDY ON KNOWLEDGE, ATTITUDE AND PRACTICE ABOUT PERSONAL HYGIENE AND DISEASE AWARENESS OF EAST WEST UNIVERSITY STUDENTS IN DHAKA CITY. Dhaka, Bangladesh.: East West University Dhaka.

[6] India, G. o. (2012). TOTAL SANITATION CAMPAIGN SANITATION FOR ALL : 2012. Government of India Ministry of Rural Development Department of Drinking Water Supply Rajiv Gandhi National Drinking Water Mission.

[7] Islam, D. S. (July,2012). A STUDY ON KNOWLEDGE, ATTITUDE AND PRACTICE ABOUT PERSONAL HYGIENE AND DISEASE AWARENESS OF EAST WEST UNIVERSITY STUDENTS IN DHAKA CITY. Dhaka, Bangladesh.: East West University.

[8] Joshi, R., \& Sirajuddin Ahmed. (17 February 2016). Status and challenges of municipal solid waste management in India: A review. Cogent Environmental Science
[9] Karn, R. R., Bhandari, B., \& Jha, N. (2012). A STUDY ON PERSONAL HYGIENE AND SANITARY PRACTICES IN A RURAL VILLAGE OF MORNAG DISTRICT OF NEPAL. Journal of Nobel Medical College , 39-44.

[10] MBULA, E. S. (2013). FACTORS INFLUENCING IMPLEMENTATION OF HYGIENE PRACTICES IN PUBLIC SECONDARY SCHOOLS IN CENTRALDIVISION OF MACHAKOS DISTRICT IN MACHAKOS COUNTY.

[11] Patil, S. R., Benjamin F. Arnold, Alicia L. Salvatore, Bertha Briceno, Sandipan Ganguly, \& Paul J. Gertler. (August 2014). The Effect of India's Total Sanitation Campaign on Defecation Behaviors and Child Health in Rural MadhyaPradesh: A Cluster Randomized Controlled Trial. PLOS Medicine, Volume 11,Issue 8.

[12] Pfadenhauer, L., \& Rehfuess, E. (2017). Towards Effective and Socio-Culturally Appropriate Sanitation and Hygiene Interventions in the Philippines: A Mixed Method Approach. International Journal of Environmental Research and Public Health .

[13] Rahul, D. A. (August 2017). UNDERSTANDING TOILET USAGE, CLEANLINESS, AND HYGIENE IN RURAL INDIA. International Research Journal of Human Resources and Social Sciences , 195-208.

[14]/ Rayamajhi, R., Budhathoki, S., Ghimire, Niraula, S., Khanal, V., Neupane, B., et al. (2014). A STUDY ON SANITARY AND HYGIENE PRACTICES. Journal of Chitwan Medical College , 20-24.

[15] Sah, R. B., Khadgi, \& Jha. (2017). Study on Knowledge and Practice Regarding Hygienic Conditions among the Residents of Rangeli Municipality of Morang District, Nepal. ARC Journal of Public Health and Community Medicine , Volume 2, Issue 1,.

[16] Tan, Cheng, Soon, Ghazali, \& Mahyudin. (2013). A qualitative study on personal hygiene knowledge and practices among food handlers at selected primary schools in Klang valley area, Selangor, Malaysia. International Food Research Journal , 71-76.

[17] Tearfund. (February 2007). Sanitation and hygiene in developing countries:. Fiangonana Batista Biblika Eto Madagasikara.

[18] Thitu, A., Kaseje, M., \& Augustine, A. (2016). Factors Influencing Latrine Coverage among the Maasai of Ildamat Location Kajiado District. Developing Country Studies , 22-27.

[19] Vivas, A. P., Gelaye, Aboset, Kumie, Berhane, \& Williams. (2010). Knowledge, attitudes and practices (KAP) of hygiene among school children in Angolela, Ethiopia. Hygiene of school children in rural ethiopia, 73-79.

Copyright (C) 2019 by author(s) and International Journal of Trend in Scientific Research and Development

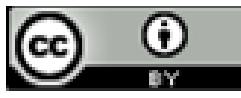

Journal. This is an Open Access article distributed under the terms of the Creative Commons Attribution License (CC BY 4.0) (http://creativecommons.org/licenses/by/4.0) 